Slađana S. Stamenković

Univerzitet u Novom Sadu

Filozofski fakultet

sladja_stamenkovic@live.com doi: 10.19090/zjik.2018.97-108

UDK 821.111(73).09 DeLillo D.

оригинални научни рад

\title{
THE CITY, THE DESERT, THE ROAD: AMERICAN CHRONOTOPES IN DELILLO'S UNDERWORLD
}

SUMMARY: In the contemporary discussion of the concept of space, there is a tendency to employ space to make a comment about the society that inhabits it. Regarding this and the prose of the contemporary American authors, the theory of Bakhtin's chronotope may be one of the most legitimate ways to depict the society of contemporary America. In the fiction of Don DeLillo, one could discuss three typical American chronotopes: the city, the desert, and the road. The said chronotopes may be interpreted within the scopes of Bakhtin's original chronotopes. They operate on both individual and mutually overlapping levels. In one way or the other, the American chronotopes mentioned seem to function as the ultimate Nowhere, space where the modern characters go to disappear in DeLillo's prose.

Key words: chronotope, DeLillo, city, desert, road

\section{INTRODUCTION AND THEORETICAL OVERVIEW}

A great study of the space-time in literature is Bakhtin's notion of chronotopes, specific intersections of time and space within literary works that carry information about particular points in human history and culture. This paper examines the chronotopes of the city, the desert, and the road in Underworld, a novel by one of the perhaps most relevant writers of the contemporary American literature - Don DeLillo. These chronotopes are realized within one larger chronotope of America, which in DeLillo's fiction is often represented as a unique Baudrillardian hyperreality, and they arguably prove to be essential for understanding the contemporary moment of American culture and identity.

\footnotetext{
${ }^{1}$ The paper is based on research done for a seminar paper of the same title for the subject Images of America in contemporary American prose: Pynchon, Auster, DeLillo under the mentorship of prof. dr. Ivana Đurić Paunović, on the second year of Ph.D. studies in 2017.

${ }^{2}$ The paper is done within the project Language and Cultures in Time and Space, No. 178002.
} 
In the postmodern theory, the notions of space and time are regarded in terms of the space-time continuum. In The Condition of Postmodernity, David Harvey discusses this continuum and its origin and uses a term "time-space compression" (Harvey 1990: 260) to define the system inhabited by the postmodern society. Concerning literature, space-time continuum also seems to be crucial for recognizing and discussing particular points in historical and cultural terms. To explain this better, one must first introduce the notion of chronotopes. The term is assigned to Mikhail Bakhtin who defined it as "the intrinsic connectedness of temporal and spatial relationships that are artistically expressed in literature" (Bakhtin 2008: 84). A chronotope, thus, is a specific spatial entity which involves more than its particular physical aspect - it carries information about the people who inhabit it at a particular moment in history and their culture. In other words, a literary chronotope "becomes charged and responsive to the movements of time, plot and history" (Bakhtin 2008: 84).

Considering the types of chronotopes, Bakhtin discussed several, which he paralleled with the ancient novel genres. For the purpose of this paper, the author suggests considering three inherently American spaces as possible chronotopes that are essential to understanding American culture. These spaces are: the city, the road, and the desert. When drawing parallels with Bakhtin's chronotopes, the three of these do somewhat relate to his original types. The most obvious analogy is that between Bakhtin's "adventure time with ordeal" novel (Morris 2007: 180) and the chronotope of the road. Within this chronotope, Bakhtin argues that "the course of an individual's life is fused with his actual spatial course or road" (Dentith 2003: 50). The road in American literature implies not only a plain journey, but a quest, usually undertaken by a hero who lacks any real roots in his life. Therefore, his whole life and its purpose are depicted as one and the same with the road - a place of no firm ground where there is no home, no goal and no planned outcome of the journey. What is more, this chronotope implies "the testing of hero's integrity and selfhood" (Morris 2007: 181); a trait which is also present within the road novels in American literature.

Concerning the city as an important space for American identity, one can discuss its connection to Bakhtin's chronotope of the "adventure novel of everyday life" (Morris 2007: 181). The similarity between the two chronotopes of adventure time does exist, but their main difference is reflected in the hero. In the first one, he must undergo a journey and face difficulties and obstacles which are to be overcome. However, within the second type, concerned with everyday life, the focus 
of the journey is slightly removed from the hero to his surroundings - he is but a witness to everyday life; he is what Baudelaire would call a flâneur - a casual, aimless wanderer. The change in the hero is an inner one, since the chronotope is built around "biographical crisis which shows how an individual becomes other than what he was" (Morris 2007: 181). In this sense, the spatial aspect of the chronotope somewhat shapes and reshapes the protagonist, whereas the temporal aspect is less dominant, since the chronotope of the city is usually less dynamic, especially compared to the chronotope of the road.

Finally, the third chronotope which is for Bakhtin the biographical novel, can be somewhat compared to the desert in American literature. In essence, Bakhtin defined this chronotope as focused on an "individual's life as seeking after true knowledge" (Morris 2007: 181). In American literature, this quest for true knowledge or enlightenment is often interpreted as the westward journey, or the conquest of the Western frontier. For the purpose of this paper one should focus on its connection to the element of the desert. While the West in the USA does not stand exclusively for a desert, when authors discuss it within the trope of the Western frontier, it is always somehow related to the wilderness. Beyond the border of civilization, there lies the land which is untamed, wild and somewhat isolated so as to bring the hero a possibility of self-reflection; a description which may as well be applied to the chronotope of the desert. This chronotope is, therefore, deeply connected to the trope of westerns and inseparable from the heritage of American first settlers. All of this seems to expand the temporal aspect of the chronotope more than the spatial one, as the element of history here inevitably shapes both protagonists and events in contemporary novels.

\section{AMERICAN CHRONOTOPES: THE CITY}

Designed to protect and bring together a community of people, the city is a pinpoint of civilization. Although the city is not an American invention, it can be argued that what we consider to be a city nowadays is seemingly primarily rooted in Western culture, although not exclusively. The first mental image one has when a city is mentioned is that of a megalopolis, a contemporary metropolis. New York stands as the ultimate example of the American city and metropolis - it is incredibly technically advanced, it is home for millions of people, it is a locus of a great number of events, and most importantly, it is one of the centers of the world's financial and economic power. However, in postmodern literature, the chronotope of the city is also associated with a more global sense; more precisely, that of a global 
village. With the postmodern space-time compression, the chronotope of the city in American contemporary literature enfolds more than geographical American soil - it engulfs a vast space of postmodern hyperreality which is worldwide and everincreasingly expanding. This way, the chronotope of the city in DeLillo's novels and contemporary literature, extends to an infinite plane of existence, a unique hyperreality that includes events and people from across the globe, brought to such global village by the means of the media. Not only is the spatial aspect of the chronotope thus expanded, but the temporal one is prolonged in the same fashion. The media and the technique of simultaneity allow for the events from both different places and historical moments to be included within the chronotope of the city at each given moment. In Underworld, this is perhaps best seen in the example of the famous baseball game between the Dodgers and the Giants. Although the game happened a long time ago, it is interwoven with the streets at which the people celebrated the victory and their private spaces where they were at the time of the game.

The chronotope of the city also implies what theoreticians define as the production of space. It is structured by various socio-political elements and its inhabitants; i.e. it is a product of the civilization. Baudrillard, among other postmodern theoreticians, often referred to the city as the point of the accumulation of the capital, since it is inseparable from its socio-economic implications. Therefore, the chronotope of the city is deeply marked by socio-economic issues that occur in contemporary society. This further opens a different level of spatial existence - the so-called social space. The social space which is formed by and for the sake of the city is of crucial significance for the interpretation of this chronotope in the novels of the said authors. The chronotope of the city is not just the spacetime continuum and the culture it involves; it is also its people and their interpersonal interactions. What this aspect of the chronotope seems to suggest is that the city has failed its original purpose. Namely, space which was constructed in order to protect its people and more importantly bring them together, when translated to the chronotope in almost all DeLillo's novels, does exactly the opposite. The American city is the locus of destruction and alienation in contemporary literature. For DeLillo, it is New York that is most frequently depicted as the representative of this chronotope. It is where people tend to isolate themselves. Such action is usually triggered by circumstances, since "the city is hard and [...] mean" (Underworld 86) which results in everyday life resembling one kind of a battle. This suggests that the spatial aspect and the aggression of its streets directly shape the protagonists within this chronotope. Almost all the characters in 
DeLillo's novels are painfully alone, whether they wish this isolation upon themselves or not. The postmodern crash of space here operates on the level of social space - the families are dysfunctional and the human interaction is meaningless. The social life in the city is perhaps best defined in Underworld by the example of Nick Shay's family. The fact that he senses more connection between himself and the advertising industry, and between the movies and his wife, than between the two of them is a tragic comment on contemporary society and consumerism. The interpersonal relationship within the postmodern chronotope of the city can be summed up by the quote from Cosmopolis, another DeLillo's novel set in New York, where Eric Packer says the following:

Eye contact was a delicate matter. A quarter second of a shared glance was a violation of agreements that made the city operational. Who steps aside for whom, who looks or does not look at whom, what level of umbrage does a brush or a touch constitute? No one wanted to be touched. There was a pact of untouchability. Even here, in the huddle of old cultures, tactile and closewoven, with passersby mixed in, and security guards, and shoppers pressed to windows, and wandering fools, people did not touch each other. (Cosmopolis 66)

Moreover, the city is enveloped in what Baudrillard calls the society of terror. This motif is most common in DeLillo's prose. In Americana, for example, David Bell openly wonders what it is like to live one's life without fearing the city. Terrorism is present in his novels as a not so distant threat even when the streets of the city are not the locus of direct violence. Underworld is implicitly threatened by the bomb, Cosmopolis almost explicitly discusses the collapse of Western civilization, whereas Falling Man most explicitly dwells on the aftermath of the most famous terroristic act in recent history. The implications of a post-apocalyptic city are strong and there is an element of fear which governs and shapes the social space of the American city. The chronotope of the city here interacts with the chronotope of the society of terror. In Underworld, this chronotope is more temporally than spatially rooted, because it is closely connected to the Cold War narrative in which there is an imminent outside threat that might bright death and destruction to the society in question. Sociologically, this chronotope is also burdened with issues like terrorism, mass shootings and wars, but also the Armageddon depicted through various conspiracy theorists. It should be noted that the latter also introduces the motif of Pynchonian paranoia since different conspiracy theories (spread by the prophet in the streets in Underworld) reinforce the belief that 
the chronotope of the city implies constant fear of destruction and death. Furthermore, death is also present within the chronotope of the city in the element of the waste. Spatially, the waste threatens to not only clog the streets of New York, but quite literally swallow it once the existing deposits of waste turn into mountains such as the one that Shay's colleagues are projecting.

Another trait which connects death with the chronotope of the city is the underground. DeLillo often employs this space below the city where counter cultures find their home within the urban setting. In Underworld, there is an underground cinema and a whole strain of avant-garde events and artistic operations. Underground also functions on a metaphorical level, since it can also be interpreted in terms of different secret groups and organizations that operate in secrecy, under the radar. On the linguistic level, underworld also implies class distinction, since it marks the lower social classes. Simultaneously, it can be argued that the underground urban spaces may be a version of private space within public one. In terms of the Self-Other binary opposition, the space of the underground is assigned to the Other, or the margin, whereas the center, or the mainstream part of society operates in the streets. This way, the chronotope of the city in DeLillo's fiction proves to be multilayered or even multidimensional. Not only does imply different spatial levels, but it implicitly separates realities depending on the people coming from different social classes and backgrounds.

\section{THE DESERT}

If we regard the city as a chronotope which represents the civilization, the desert might arguably be the point where all traces of civilization are absent. The desert does stand for nature, as opposed to the civilization, but it is in no case a positive counterpart in this binary opposition because it is barren. As such, it can be interpreted as the ultimate nowhere in modern and postmodern fiction. Salmela supports this claim by stating that "the modern cultural imagery" associates the desert with "nowhere" or "a spatial entity detached from known spatiality" (Salmela 2008: 132). In this sense, the chronotope of the desert is spatially both infinite and non-existent.

Temporally and historically, the chronotope of the desert is connected to the notion of the American West and the Western frontier narratives and myths which imply a heroic battle of a man with the wilderness and unexplored land. In postmodern fiction, however, this battle translates itself to a more psychological 
level, since the westward journey usually implies a quest for some deeper knowledge about the world or the Self. Salmela explains this postmodern narrative using the example of Paul Auster's characters who "undergo major personal transformations in the barren lands of the U.S. Southwest" since it "represents the image of the self as tabula rasa that connects Auster's fiction to the American mythology of fresh new beginnings and re-created identities" (Salmela 2008: 132). In a similar fashion, DeLillo's David Bell in Americana will set on a journey to the desert where he intends to find some deeper knowledge about his true Self. The deeper knowledge that lies hidden in the desert also makes the desert real, as seen particularly in Underworld when the protagonist says that "[i]t was too big, too empty, it had the audacity to be real" (Underworld 449). Given the fact that DeLillo's America struggles in the hyperreality where only simulacra are present, this description of the desert may come as a compliment. Furthermore, in Point Omega, the desert is also a place of silence and peace; "out beyond cities and scattered towns. [...] There was the house and then nothing but distances, not vistas or sweeping sightlines but only distances. He was here, he said, to stop talking" (Point Omega 18).

Yet the implications of the desert are not only related to self-discovery. The element of both violence and death within the chronotope of the desert is very prominent in DeLillo's novels. Primarily, DeLillo associates the desert with the sites of military bases or testing fields. In Underworld, this aspect of the chronotope is depicted through the character of Nick Shay's brother Matt, whose military career has a defining influence on his life. In his mind, nuclear weapon development is inseparable from the desert, bringing the element of death directly to this chronotope. This particular episode serves another purpose when it comes to chronotopes - it goes to show that they are also temporally defined by individual memories in addition to the objective and official history. In this sense, DeLillo allows a possibility of multiple chronotopes of the desert, each marked with personal histories, fears and traumas. Still, one way or the other, the emptiness and death are inevitably present within this chronotope. Even when the desert is not necessarily involved with warfare, there is some element which associates it with war and destruction. In DeLillo's Point Omega, Richard Elster retreats to the Arizona desert following the aftermath of his war experience in Iraq. Specifically in Underworld, it is also where Klara Sax finds refuge for her art. Sadly, her art is associated with the army and American violent past, too - her artistic project is in essence a restoration of old, decaying airplanes that participated in World War Two. 
Another level of interpreting the chronotope of the desert in postmodern literature is related to the previous one - the city. Namely, the two of "America's mythological surfaces" (Jarvis 1998: 38) may be one and the same chronotope in American postmodern prose. In other words, the city might also operate as the chronotope of the desert. At this point, we can discuss the overlapping of different chronotopes in DeLillo's novels marked with multidimensionality in every sense of the word. Concerning American contemporary prose, Cohen argues that "the displacement of desert onto city becomes a governing motif" in Auster's novels (Cohen 2000: 101) and the same can be said for DeLillo. He ascribes this to the notion of placelessness which is "common to both street and sand" (Cohen 2000: 101). Placelessness can be achieved through "canceling the objective reality by creating an illusion of the place" (Đurić Paunović 2014: 102) which is usually achieved by the means of some filters (the media, technology, or plain walking). In America, Baudrillard calls the city "the reproduction of a mythical desertscape [...] the finished form of the future catastrophe of the social" (Baudrillard 1989: 5). This way, we can regard the city as one possible interpretation of the chronotope of the desert.

In DeLillo's novels, the city is perhaps more of a jungle than a desert, but it is a wild space, nevertheless. The similarity between the chronotopes of the city and the desert operate in relation to the aforementioned terror and violence. The city in DeLillo's novels functions as a global hyperreality, a vast space strongly connected to the concept of disappearance. The city is where DeLillo's characters go to disappear, whether by completely blending in the social patterns of behavior of the urban space or by completely renouncing of them. For example, DeLillo's characters often behave a certain way just because it is expected of them (Marian and Nick Shay from Underworld have affairs which they keep a secret only because they are supposed to do so). This way, voiding their lives of authentic meaning, they question the authenticity of the reality they inhabit and, in turn, its realness. By not being really present in their lives and the space-time they inhabit, they create a relative plane of existence which they simultaneously inhabit and are absent from. Once the space-time around them becomes relative, their plane of existence may be interpreted as the notorious Nowhere, in which the city is just a postmodern, urban interpretation of the chronotope of the desert.

\footnotetext{
${ }^{3}$ Translated into English by the author of the paper.
} 
The interchangeability of these chronotopes is further enhanced by the EastWest binary so deeply connected to American culture. Generally, the East is seen as connected to Western civilization and urban setting, thus connecting it, at first glance, with the chronotope of the city. As opposed to this, the West is the vast, unconquered land which corresponds with the chronotope of the desert. Yet, in Underworld, this general view is challenged. Nick Shay, who moved to the West, sees the East, and particularly New York, as a vast, wild land of his memories, a barren place of trauma. The East for him is more temporally charged, as it stands for the past, much like the chronotope of the desert primarily stands for the historic heritage of American settling. The West, his new home, is connected to order, careful planning and urban context; i.e. everything opposite to the mythical West from the American tradition. His life and even the journey to the desert are also deeply marked by the city by the means of his memories. Once he goes to visit Klara Sax, his old affair, New York is as vivid for him in the desert as it is on the East Coast. This chapter in particular highlights the importance of human activity within any given space.

\section{THE ROAD}

Human activity, and especially the motion are essential to yet another chronotope that is typical for American postmodern literature and the genre of the road novel, and that is the road. Essentially, this chronotope includes an open road, which can be interpreted as a mark of the civilization on the land - it stands as a testimony to the human conquering of the infinite wilderness. This way, it may be said that it combines elements of the previous two chronotopes discussed here. The road, in its original sense, connects two points over a vast space of nothingness. Yet, even though the road technically connects two or more points (i.e. it has a beginning and an ending), this chronotope includes a lack of both destination and home, or the place of origin. In other words, it is the journey that is important in postmodern literature, and the road represents a space which is essentially rootless within this chronotope. Moreover, the chronotope of the road also coincides with the concept of Nowhere, since it is a perfect example of the postmodern space-time compression. Although it physically implies linearity, this chronotope challenges both temporal and spatial linearity, as well as the linearity of narration. The dynamics of the events along the journey depends solely on the protagonist and his mind, his inner quest and journey. This chronotope is thus equally temporally and spatially ambivalent, since there are no firm points that connect it to a specific environment and culture. It is one of the most universal chronotopes in literature, since it opens a chance of 
intercultural conversation, quite literally representing a transition from one point of view to another. Metaphorically, in Underworld, DeLillo takes the reader on a journey through American history, and in particular, the history of the media. The whole American culture in this novel, in a more loose interpretation, is on a Westward journey (much like Nick and the baseball clubs), expanding their boundaries, but seemingly never finishing the journey, remaining in transition. For example, Nick moves to Phoenix, but he is far from a man who found his final destination, mainly because he encounters the same lack of realness in the West that he escaped from in the East.

The road may include a considerable journey across the vast spaces of the desert, but it can also stand for the streets of the city, just as long as it is a space where an aimless journey occurs. This way, the chronotopes of the city and the road seem to overlap. In DeLillo's fiction, this can be exemplified more appropriately by the day-long journey of Eric Packer in Cosmopolis who spends his entire day on wheels, going essentially nowhere. Yet, although there is a sense of rootlessness in his journey, there is a destination - and a rather fatal one; he is traveling towards his destruction. Underworld does not necessarily depict the journey in the streets of New York per se, but sporadic comments of the real streets from the protagonists' memory that once were the site of unity and celebration (but no longer are) seem to suggest the eerie quality of streets stripped of familiarity and cordiality. In other words, the streets within the chronotope of the city are no longer filled with genuine interaction between people, but are just roads intersecting with other roads. The lack of true and fulfilled social space is what contributes to the interpretation of the streets as the urban version of the chronotope of the road. For DeLillo's characters, the road and the journey implied for the characters are essentially but a means of running away from themselves, and thus of disappearance. Baudrillard himself called driving a "spectacular form of amnesia" (Baudrillard 1989: 8) which leads to "evaporation of meaning" (Baudrillard 1989: 9). In that sense, the journey is its own purpose; the characters travel not to obtain their goals, but to get lost on the road, in the speed, in the self-sufficient motion. The characters are essentially nowhere they lose themselves in the crowds and on the streets, thus disappearing from the space completely.

\section{CONCLUSION}

In the novels of Don DeLillo, the author seems to use the notion of space to not only develop the story, but also influence the lives of their protagonists. The 
chronotopes of the city, the desert, and the road almost determine the entire environment of contemporary America in their novels. On their own or when intertwining, these chronotopes are perhaps the crucial points at which the story of not only postmodern America, but also the postmodern world is unraveled.

What all of them have in common is that they bring about the so-called postmodern condition $-\mathrm{a}$ society that is alienated. The hero from Bakhtin's chronotopes had his adventures, difficult quests at which he is to prove his integrity and character, but he was able to overcome his obstacles and obtain his happy ending. In postmodern literature, the hero has no important undertakings other than to find a true knowledge of oneself, a quest that often proves unsatisfactory. Hence, the protagonists of the contemporary authors, and DeLillo in particular, are eager to disappear. The chronotopes of the city, the desert, and the road seem to be perfect accomplices since they all prove to be but different incarnations of the ultimate nowhere.

\section{BIBLIOGRAPHY}

Bakhtin, Mikhail. 2008. "Forms of Time and of the Chronotope in the Novel." The Dialogic Imagination. Ed. M. Holquist. Austin: University of Texas Press. pp 84-258.

Baudrillard, Jean. 1989. America. London: Verso.

Cohen, Josh. 2000. "Desertions: Paul Auster, Edmond Jabès, and the Writing of Auschwitz." The Journal of the Midwest Modern Language Association, 33/34, 94-107.

DeLillo, Don. 2003. Cosmopolis: A Novel. New York: Scribner.

DeLillo, Don. 2011. Point Omega: a Novel. New York: Picador.

DeLillo, Don. 1997. Underworld. New York, NY: Scribner.

Dentith, Simon. 2003. Bakhtinian Thought: Intro Read. London: Routledge.

Đurić Paunović, Ivana. 2014. Čudnoliki svet: američki hronotopi Pola Ostera. Beograd: Geopoetika.

Harvey, David. 1990. The Condition of Postmodernity: An Enquiry into the Origins of Cultural Change. Oxford: Blackwell.

Jarvis, Brian. 1998. Postmodern Cartographies: The Geographical Imagination in Contemporary American Culture. London: Pluto Press.

Morris, Pam. 2007. The Bakhtin Reader: Selected Writings of Bakhtin, Medvedvev, Voloshinov. Hoboken: Blackwell Publishers. 
Salmela, Markku. 2008. "The Bliss of Being Lost: Revisiting Paul Auster's Nowhere." Critique: Studies in Contemporary Fiction 49.2, 131-148.

\section{Slađana Stamenković}

GRAD, PUSTINJA, PUT: AMERIČKI HRONOTOPI U PODZEMLJU DONA DELILA

$$
\text { Rezime }
$$

Kada govorimo o savremenim proučavanjima prostora u književnosti i teoriji, često se ovaj pojam koristi da bi se kritikovalo i opisivalo društvo koje pomenuti prostor nastanjuje. U savremenoj američkoj prozi, čini se da je pojam Bahtinovog hronotopa jedan od najboljih načina da se posmatra društvo savremene Amerike. Ovo se da primetiti na primeru romana savremenog američkog pisca Dona DeLila. Štaviše, $u$ Podzemlju može se pratiti značaj tri tipična američka hronotopa, a to su: hronotop grada, hronotop pustinje i hronotop puta. Svi oni su, u manjoj ili većoj meri, moderna paralela originalnih Bahtinovih tipova hronotopa, i u pomenutim delima funkcionišu samostalno ili se međusobno prepliću. U ovom ili onom slučaju, ipak, moguće ih je interpretirati kao prostor gde ne postoji ništa, jer DeLilovi junaci u njih odlaze kako bi nestali.

Ključne reči: hronotop, DeLilo, grad, pustinja, put 